\title{
Case Study Report - Impact on Access to HIV Care by UN Plus Kenya
}

\author{
Article by Jane Sinyei - March 2014 \\ PhD in Psychology, Texila American University, Kenya \\ Email: Jerono123@Texilaconnect.Com
}

\begin{abstract}
In this study which looks at the impact on access to HIV care by UN Plus Kenya, the researcher interviewed 41 staff members living with HIV. The interviews took place in one of the UN Plus meetings. For those who were unavailable at the meeting/non UN Plus members, the researcher sought for appointments with individual members while keeping confidentially during the process. The literature review revealed a similarity in the outcome of viral load suppression. The data revealed some few staff members who were not doing as well as the others and who may have to be followed up for further care.

Adequate time is required to give more attention and better analysis of all the results from this study.
\end{abstract}

\section{Introduction}

HIV is still a problem within the UN workplace. UN Cares, the HIV workplace program which aims at reducing the impact of HIV at the UN workplace has been operating in the Kenya UN system since 2003. This is the same year that free access to HIV treatment and care was made to staff living with HIV . 2013 was therefore the 10th anniversary since the program of access to care was started. The study was done to assess impact of care on staff living with HIV over the past 10 years as they commemorated the World AIDS Day on 1st December 2013.

\section{Review of literature}

The HIV (Human Immunodeficiency Virus)and AIDS (Acquired Immunodeficiency Syndrome) epidemic is a global crisis and forms one of the most formidable challenges to development and social progress (ILO, 2001).

Prevalence is the number of cases of a given disease (or other health conditions), in a particular population, at a given time. This is expressed as a percentage of all persons who can have the disease. Prevalence can increase or decrease over time depending on the number of new infections, the rate of mortality, the availability of treatment and surveillance methods (NASCOP, 2008).

HIV and AIDS has been described as a pandemic phenomenon in Kenya, (UNAIDS, 2002). Kenya's former president Daniel arap Moi declared it a national disaster in 1999.

HIV and AIDS is one of the leading global health issues, though manageable it can be a killer disease with no cure. In the latest statistics Sub-saharan African where Kenya is found is still leading in the HIV prevalence.

The number of people living with HIV are 25 million $(23.5 \mathrm{~m}-26.6 \mathrm{~m})$ in Sub-Saharan Africa (UNAIDS, 2013). Sub-Saharan Africa also leads in the estimated number of deaths among adults which is at 1.2 million (1.1m-1 .3m)as at 2012 (UNAIDS, 2013).

The UN system in Nairobi is the largest established duty station in Africa. It is has approximately 75 agencies, programs and funds. In Kenya 120 staff members are known to be living with HIV and are on antiretroviral treatment. It is estimated that a further 331 staff members and their dependents are infected (UNAIDS, 2005).

UN Plus, the United Nations system HIV Positive staff group (UN Plus, 2014) is found in countries globally including Kenya. The Kenya chapter had 54 members by end of 2011 (UN Plus, 2014). UN Plus has a joint budget with UN Cares, the UN workplace program on HIV 
South American Journal of Public Health

Special Edition May 2016

and AIDS. UN Plus makes sure that staff living with HIV are adequately engaged in prevention activities, are offered psychosocial support, address stigma and discrimination, etc (UN Plus, 2014).

UN Cares, the HIV/AIDS workplace program is in place to reduce the impact of HIV in the UN workplace by supporting "universal access" to a comprehensive range of benefits, including prevention, treatment, care and support for all personnel and their families. The UN Cares 10 Minimum Standards are the least criteria that a UN agency must meet at their workplaces. Their benefits are to:

- help save lives and improve staff well-being, reduce stigma and discrimination, and sustain the UN's capacity to do its core work;

- establish a common implementation framework to realize the UN Personnel Policy on HIV/AIDS; and

- serve as a model of the UN reform process by "Delivering as One" an HIV workplace program that builds on existing workplace efforts of various UN agencies, while eliminating duplication of effort. (UN Cares, 2014).

CD4 cells are white blood cells that fight off infections in the human body. A CD4 lymphocyte cell is a cell of the immune system that carries the CD4 surface protein. CD4 cells are very important to a normal health immune system. CD4 cells attract HIV. HIV infects and kills CD4 cells, leading to a weakened immune system (NASCOP, 2008).

A viral load test counts the number of HIV particles in a sample of blood. The result is expressed as the number of 'copies 'of HIV RNA per ml (milliliter)of blood. It is generally accepted that 10000 copies per $\mathrm{ml}$ or less is taken as low and 50000 copies per $\mathrm{ml}$ and above is considered high (Health 24, 2014).

As per the article on understanding the viral load, there are several tests that measure the amount of HIV. However, the tests become unreliable at low levels of infection. Originally, this limit was less than 400 or 500 copies per ml. New 'ultra-sensitive 'tests are there that measure a lower limit of 50 copies per ml. Depending on the test used, a measurement below the limit of detection may be referred to as 'undetectable'(Health 24, 2014).

A viral load test is one of the assessment tests that can indicate disease progression and may give an indication as to the likely course of HIV infection, if left untreated. It is generally accepted that a higher viral load may lead to more speedy disease progression. Other indicators such as CD4+ count and opportunistic infections should also be considered when deciding to take treatment (Health 24, 2014).

When initiating treatment, the viral load test shows some indication of how effective the anti- HIV regimen is. When commencing on treatment, or changing from one treatment to another, an individual should have a baseline viral load test prior to the start or switch of drug therapy. A subsequent test should follow a couple of months later, so as to assess the effect of the drugs. It is then normal to have repeat tests every six months or more frequently, if there are indications that the regimen is not working (Health 24, 2014).

\section{Objectives \& hypothesis}

The objectives of the study were among other things, to access the CD4 and viral load counts at the onset of initiating therapy and at the current time of the study. This study aims to see if there is some impact on provision of care to staff accessing HIV treatment and care.

\section{Method}

Methodology is a system of methods and rules to facilitate the collection and analysis of data. It provides the starting point for choosing an approach made up of theories, ideas, concepts and definitions of the topic, therefore the basis of a critical activity comprise of making choices about the state and character of the social world [assumptions]. This should not be confused with techniques of research, the application of methodology (Hart, 1998). 


\section{Participants}

The participants numbered 41 , 18 male and 23 female aged between 25 and 60 . They came from 10 United Nations agencies in Kenya. These were as follows:
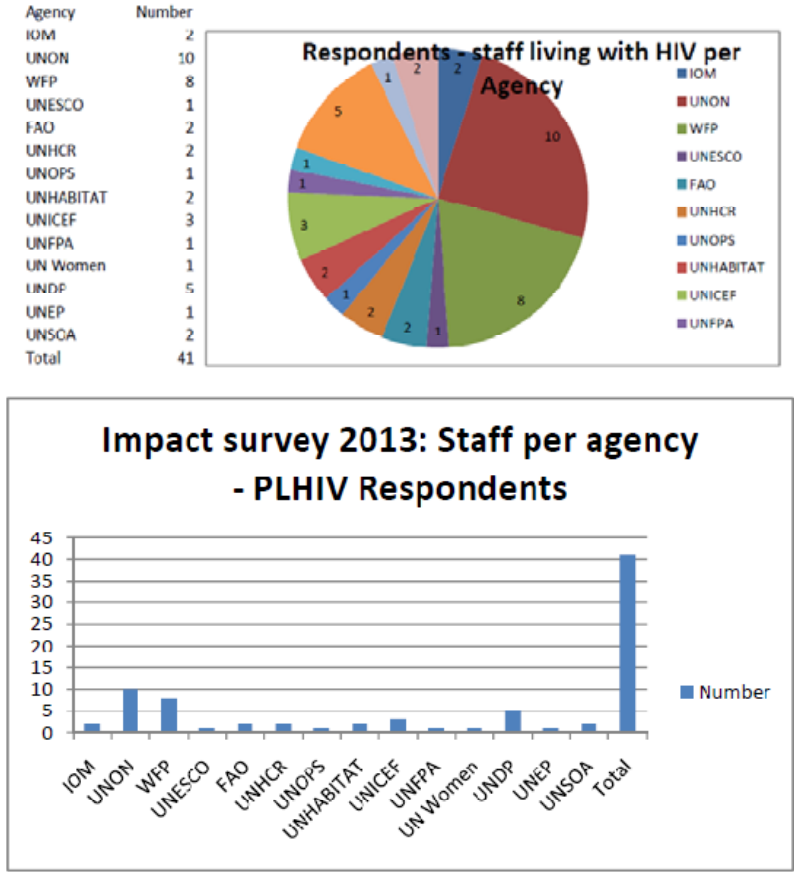

\section{Procedure}

My plan was to administer a questionnaire on the participants through the website designed survey - survey monkey where one keys in own questions. However, after consultations with my supervisors I changed the method to direct interviews. The answers from participants were collaborated by laboratory tests in their possession. The criteria for choosing this group is that there is trust and rapport among the members where confidentiality was key. The other method used was direct observation where I noted down whether one was female or male.

In this study, I collected a wide variety of data that included identifying those who had joined the support group or not, deaths over the last ten years, HIV status of babies born to staff living with HIV , drug interaction, HIV learning, sick leave, hospitalization, opportunistic infections, disclosure, CD4 and viral load counts. In this study I shall confine myself on two areas that I believe will bring out the impact of access to care while meeting purpose of this case study report.

During the design phase of a case study research, the researcher determines what approaches to use in choosing single or multiple real-life cases to examine in depth and which instruments and data gathering methods to use. $\mathrm{W}$ hen using multiple cases, each case is treated as a single case. Each cases conclusion can then be used as information that contributes to the whole study. However, each case remains a single case (Yin, 1984). As per $\mathrm{Y}$ in (1984) I am therefore in order by choosing a portion of the data collected to analyze and interpret.

Privacy, including maintaining the confidentiality and anonymity of data, is critical to both researchers and therapists. Interview transcriptions are anonymous, a code number or a name usually given to each participant. Confidentiality concerns the matter of who has access to the data. The informed consent agreement should specify who has access to the data (Morse, 1994).

I sought consent from the Global UN Plus Coordinator. This was provided (see Appendix 1a). Consent from my participants before carrying out the interviews was sought (see 
South American Journal of Public Health

Special Edition May 2016

Appendix 1b). I gave each participant a number so that their identity would remain anonymous.

\section{Results}

The respondents were diagnosed ranging from a period of 19 years to 2 weeks at the time of this study. Those diagnosed earlier and had initiated treatment had a better CD4 count and a suppressed viral load. These were mainly the UN Plus members who appeared to be doing better than those who had not joined this support group.
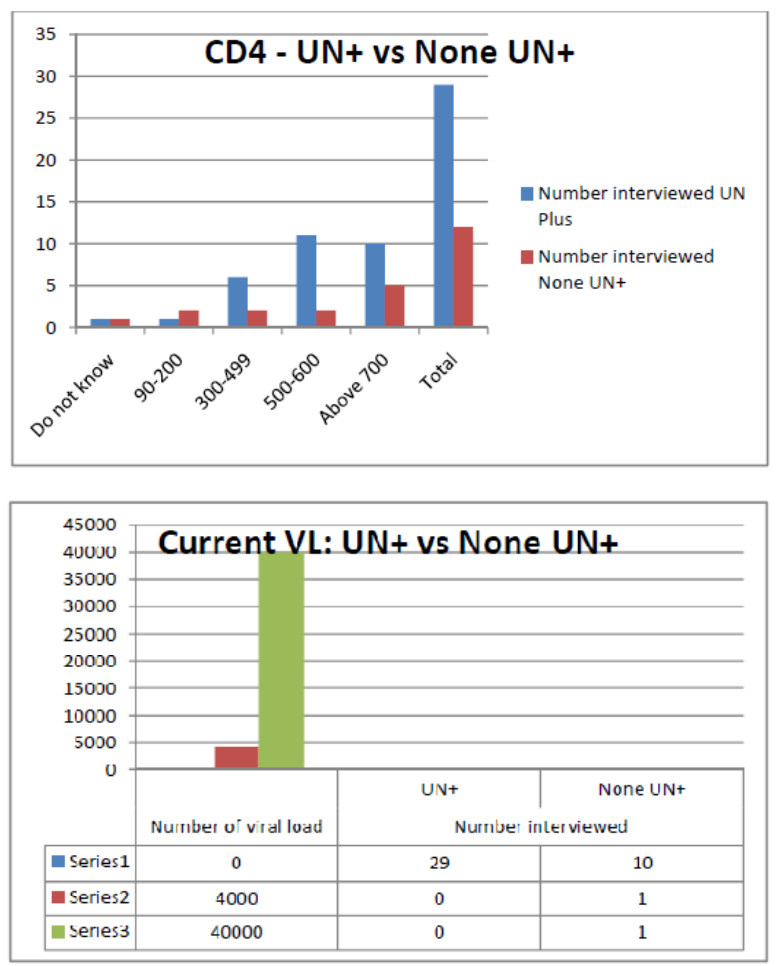

Out of the 41 respondents, one had a viral load of 4,000 and the other 40,000. They had 1 and 2 years respectively of treatment/access to care. Three (3)did not know their present viral load. At the beginning of initiating therapy the viral load for some were in thousands and others in millions. One had 50 copies, a second had 112 copies and the rest had from 7200 to millions.

\section{Discussion}

It is noticeable that viral load counts for most of the UN Plus members after some time was undetectable apart from the two who still had detectable levels. In a study on long-term outcome of second line antiretroviral therapy, they observed a high degree of viral suppression at 12 months and little loss of viral suppression thereafter (Sagepub, 2014).

The staff not yet in UN Plus, the support group whom I shall call 'loners' might have challenges in adhering to treatment and may not benefit from group therapy. As Corey (2000) says that group counselling tends to be growth oriented. The emphasis is on discovering internal resources of strength. The group provides the empathy and support necessary to create the atmosphere of trust that leads to sharing and exploring these concerns. Feltham $\&$ Horton (2000) do admit that there is a problem with 'isolates'. They find it difficult to access sources of psycho-social support.

Time factor has been a limitation in this study and more so in analyzing the data appropriately. I do find the results very important for my work. However, due to time factor I will still have to work on the analysis of the data, include all areas studied for use by my organisation. 


\section{Summary and Implications of the Study}

The study shows a clear positive impact on viral suppression which is key to managing HIV. In this way staffs are kept healthy and are able to do their work without much interruption. However, there is further need to follow up and investigate on the few cases that have detectable viral loads even after initiating treatment.

\section{References}

[1.] Corey (2000).Theory and Practice of Counselling and Psychotherapy.(6th Edition). Belmont CA: Brooks/Cole

[2.] Feltham, C. and Horton, I. (2000).Handbook of Counselling and Psychotherapy. London: Sage Publications Limited.

[3.] Hart, C. (1998). Doing Literature Review. Releasing the Social Science Research Imagination. London: Sage Publications Limited.

[4.] ILO, 2001. An ILO Code of Practice on HIV and AIDS and the World of Work. Geneva: ILO.

[5.] Long-Term Outcome of Second-Line Antiretroviral Therapy in Resource-Limited Settings.(3rd April, 2014). Retrieved From http://jia.sagepub.com.

[6.] Living Positively: Country Networks - Kenya.(1st April 2014).Retrieved From www.unplus.org.

[7.] Morse, J. M. (1994). Critical Issues in Qualitative Research Methods. London: Sage Publications Limited.

[8.] NASCOP. (2008). Kenya AIDS Indicator Survey KAIS. Preliminary Report. Ministry of Health, Republic of Kenya. Nairobi: NASCOP.

[9.] The Basics: What is UN Cares? ( 1st April 2014).Retrieved From www.uncares.org. www.uncares.org.

[10.] UNAIDS. (2002). Mainstreaming gender into the Kenya National HIV and AIDS strategic Plan 2000- 2005. Nairobi: Information Management Consultants.

[11.] UNAIDS.(2005). UN System HIV Workplace Programmes.HIV Prevention, Treatment and Care of the UN System employees and their families. UNAIDS best practice collection.

[12.] UNAIDS. (2013). UNAIDS Global Report. UNAIDS Report on the Global AIDS Epidemic.

[13.] Understanding Viral Load vs CD4 Count.(8th April 2014).Retrieved From www.health24.com.

[14.] Yin, R. K. (1984).Case Study Research: Design and Methods. Newbury Park, CA: Sage. 